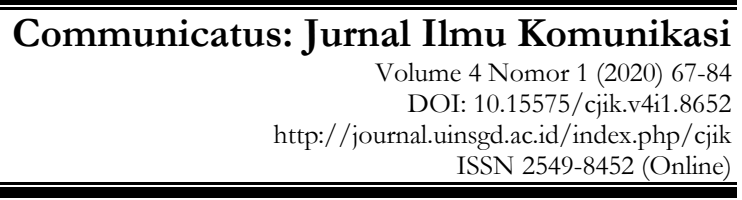

\title{
Motif dan Makna Berjilbab Mahasiswi Komunikasi Universitas Tadulako Palu
}

\author{
Sitti Murni Kaddi ${ }^{1 *} \&$ Enjang Muhaemin ${ }^{2}$ \\ ${ }^{1}$ Universitas Tadulako Palu \\ 2UIN Sunan Gung Djati Bandung \\ *email: unni_kaddi@yahoo.com
}

\begin{abstract}
This research-based paper aims to find out the motives and meanings of wearing headscarves by the students of Communication Studies at the Faculty of Social and Political Sciences, Tadulako University, Palu. The study uses qualitative research methods, with in-depth interview techniques, and observation, to explore the motives and veiled meanings of the female students. The research uses a phenomenological approach. The results of the study concluded two things. First, the causes of female students wearing headscarves are divided into two, namely the motives of the past and the motives of the future. Purposes of the past are encouraged because of encouragement and advice from parents and family, as well as shar' $i$ motifs based on obligations established by Islam. The future motives underlying the female students to wear the veil are divided into the motivation of wanting to avoid bad things, wanting to control behavior, and wanting to be appreciated. Second, related to self-meaning, the students who wear the hijab interpret it as proof of love for God, and as a service to both parents.
\end{abstract}

Keywords: wearing hijab; meaning of veiling; student motives.

\begin{abstract}
ABSTRAK
Tulisan berbasis penelitian ini bertujuan untuk mengetahui motif dan makna pemakaian jilbab yang dilakukan para mahasiswi Ilmu Komunikasi FISIP Universitas Tadulako Palu. Penelitian menggunakan metode penelitian kualitatif, dengan teknik wawancara mendalam, dan observasi, dengan tujuan menggali motif, dan makna berjilbab para mahasiswi. Penelitian menggunakan pendekatan fenomenologis. Hasil penelitian menyimpulkan dua hal. Pertama, motif mahasiswi memakai jilbab terbagi menjadi dua, yaitu motif masa lalu dan motif masa depan. Motif masa lalu didorong karena dorongan dan nasehat dari orang tua dan keluarga, serta motif syar'i yang didasarkan pada kewajiban yang ditetapkan Islam. Adapun motif masa depan yang mendasari mahasiswi menggunakan jilbab terpilah pada motif ingin menghindari hal-hal buruk, ingin mengontrol tingkah laku, dan ingin dihargai. Kedua, berkaitan dengan makna diri, para mahasiswi pemakai jilbab memaknainya sebagai bukti sayang kepada Allah, dan sebagai bakti kepada kedua orang tua.
\end{abstract}

Kata kunci : memakai jilbab; makna berjibab; motif mahasiswi. 


\section{PENDAHULUAN}

Islam merupakan salah satu agama yang ada di berbagai belahan dunia yang mengikat kuat para penganutnya dengan ketentuan syar'i yang berdasarkan pada sistem aqidah Islamiyah. Islam bukan hanya mengatur bagaimana manusia melakukan komunikasi dengan Allah SWT., tetapi juga mengatur bagaimana interaksi manusia dengan sesamanya, dan makhluk lainnya. Termasuk di dalamnya, Islam juga mengatur ketentuan dan tata cara berpakaian bagi umat Islam, terlebih khusus bagi para muslimah. Bagi perempuan muslimah, Islam menggariskan agar menutup auratnya, salah satunya dengan menggunakan jilbab.

Dalam mengimplementasi ketentuan syari'at bagi para penganutnya, Islam bukan hanya mengatur tata cara hablum minallah, tetapi juga memberikan ketentuan yang terkait dengan hablum minannas. Komunikasi dengan Tuhan, dan komunikasi dengan sesama manusia. Dalam Islam, terdapat beberapa ketentuan dan aturan untuk umat Islam dalam menjalankan kehidupannya, salah satunya adalah ketentuan substansial di dalam menutup aurat, termasuk dalam masalah berjilbab. Islam memuliakan umat manusia, di antaranya dengan membedakan batas antara aurat laki-laki dan perempuan sebagai ikhtiar manusia dalam menjaga kehormatan.

Dalam Islam, menjaga aurat bukan hanya sebagai bentuk menjaga harga diri tetapi juga dalam kerangka menumbuhkan nilai budi pekerti yang baik. Dalam Islam, aurat merupakan salah satu harga diri manusia yang harus dijaga dengan baik. Untuk menjaga aurat perempuan, kaum perempuan yang beragama Islam diwajibkan untuk menutup auratnya dengan berpakaian yang baik atau biasa disebut berjilbab. Dalam Annur ayat 21, Allah bersabda, "Katakanlah kepada wanita yang beriman, hendaklah mereka menahan pandangannya, memelihara kemaluannya, dan janganlah mereka menampakekan perbiasannya, kecuali yang (biasa) nampak daripadanya."

Dengan demikian jelas bahwa dalam aturan berpakaian, khususnya bagi perempuan muslimah, sudah ada ketentuannya dalam agama Islam. Menutup aurat dengan berjilbab memang bukanlah perkara mudah. Satu di antaranya, tergantung pemahaman para muslimah di dalam menaati syari'at Islam di dalam menutup aurat atau menggunakan jilbab. Busana muslimah atau jilbab bagi perempuan muslimah merupakan simbol di dalam berinteraksi dengan masyarakat dalam kehidupan sehari-hari. Interaksi merupakan bagian dari kegiatan komunikasi, berhubungan dengan kebutuhan manusia, sehingga terpenuhinya kebutuhan berinteraksi dengan manusia-manusia lainnya (Muchtar et al., 2016).

Dalam realitas sosial, keberagaman pengetahuan dan sikap kaum perempuan muslimah terhadap penggunaan jilbab masih nampak. Termasuk motif dan pemaknaan mereka di dalam menggunakan jilbab. Sebagian telah menggunakan jilbab, dan sebagian lainnya masih belum menggunakan jilbab. 
Dalam kontek telaah dalam tulisan ini, perempuan muslimah yang sudah berjilb pun sejatinya ada hal yang menarik untuk dikaji lebih mendalam, terutama terkait motif dan makna mereka di dalam menggunakan jilbab.

Islam sebagai agama yang bersifat universal yang mengatur seluruh aspek kehidupan manusia, di dalamnya terdapat ketentuan yang mengatur masalah pakaian, terkhusus bagi perempuan, yang digunakan sebagai penutup aurat. Dalam Al Qur"an ditegaskan bahwa batas aurat perempuan adalah seluruh tubuh kecuali muka dan telapak tangan hingga pergelangan tangan, sehingga bagi perempuan diwajibkan untuk menggunakan jilbab. Memakai jilbab menjadi ibadah dalam memenuhi ketentuan syari'at Islam. Tujuannya, selain agar terhindar dari bahaya zina, pergaulan bebas dan fitnah.

Penelitian tentang jilbab memang bukan hal baru. Namun dari setiap penelitian memiliki kebaruan dan keunikan yang berbeda. Terkait dengan penelitian penulis tentang penggunaan jilbab ini, setidaknya ada sejumlah penelitian yang menarik dipaparkan sekaligus untuk menunjukkan pembeda dalam sisi kebaruan dan keunikanya dengan penelitian penulis.

Pertama, penelitian berjudul Pemaknaan Penggunaan Jilbab Syar'i di Kalangan Mahasiswa Psikologi (Studi pada Forum Mahasiswa Islam Psikologi (FORMASI) Ar-Ruuh Universitas Medan Area). Riset yang dilakukan Nazla Putri Utari dan Nina Siti S. Siregar ini bertujuan mengetahui makna penggunaan hijab syar'i pada mahasiswa Psikologi Universitas Medan Area, khususnya pada organisasi Forum Mahasiswa Islam (Formasi) Psikologi Ar-Ruuh. Tujuan lainnya mengetahui konsep diri mahasiswa yang memakai hijab syar'i dan pendapat orang lain terhadapnya. Data yang dikumpulkan melalui observasi, kajian pustaka, dan wawancara. Analisa semiotik menjadi pilihan dalam penelitian ini. Hasil risetnya menunjukkan bahwa pengguna hijab syar'i menganggap hijab sebagai pelindung dari tatapan laki-laki yang bukan muhrim, mengajarkan kepada perempuan muslim lainnya kebaikan dan kegunaan menggunakan hijab. Konsep diri pengguna hijab syar'i terbentuk dengan belajar dari lingkungan. Pelajaran dan pengalaman yang didapat membuat konsep diri yang lebih baik.

Pembeda penelitian penulis dengan penelitian Utari dan Siregar di atas terletak bukan hanya pada siapa yang ditelitinya, dan apa yang ditelitinya, tetapi juga berbeda di dalam analisisna. Bila penelitian Utari dan Siregar itu meneliti penggunaan jilbab syar'i mahasiswa mahasiswa psikologi, penelitian penulis meneliti penggunaan jilbab pada mahasiswa komunikasi. Riset Utari dan Siregas memokuskan kajian pada makna dan konsep diri, sementara penelitian penulis lebih terfokus pada motif dan makna berjilbabnya. Dari sisi analisis juga berbeda. Bila penelitian Utari dan Siregar menggunakan pendekatan analisis semiotik, penelitian penulis lebih menekankan pada pendekatan fenomenologis.

Kedua, penelitian bertajuk Makna Berhijab Bagi Muslimah: Sebuah Persepsi 
Mahasiswa FISIP Universitas Muhammadiyah Kendari. Dalam riset ini Patta Hindi Asis menuturkan bahwa jilbab merupakan simbol agama Islam sebagai penanda kesalehan perempuan. Seiring waktu, jilbab tidak semata dimaknai sebagai bentuk kesalehan, namun juga sebagai eksistensi sebagian perempuan dalam mode berbusana di tengah-tengah masyarakat. Dalam perkembangannya, jilbab mengikuti permintaan pasar, yang pada akhirnya jilbab dibuat lebih fashionable semata-mata agar laku di pasaran. Studi kasus dan pengalaman peneliti dalam berinteraksi dengan mahasiswi yang menggunakan jilbab di kelas menjadi metode yang digunakan dalam mengumpulkan data. Sosiologi kritis digunakan untuk melihat fenomena dalam studi ini. Penelitian ini menemukan bahwa sebagian muslim mempersepsikan dirinya bahwa jilbab adalah kepatuhan terhadap ajaran agama, sebagian menyebutkan bahwa memilih berjilbab karena tuntutan gaya hidup.

Pembeda penelitian penulis dengan penelitian Azis bukan hanya terletak pada siapa siapa yang diteliti, dan apa yang diteliti, tetapi juga berbeda di dalam pendekatan analisisna. Bila Aziz meneliti penggunaan jilbab pada mahasiswi FISIP Universitas Muhammadiyah Kendari, sementara penulis meneliti penggunaan jilbabpada mahasiswi komunikasi Universitas Tadulako Palu.Riset Azis mmemokuskan kajian pada makna dan persepsi, penulis lebih terfokus pada makna dan motif. Penelitian Azis menggunakan studi kasus, penelitian penulis lebih pada pendekatan fenomenologi.

Ketiga, penelitian berjudul Proses dan Motif Berjilbab Standar ke Syar'i pada Pelajar MA Al Irsyad Gajah. Dalam risetnya ini, Abdul Choliq memaparkan perubahan mode berjilbab standard ke syar'i yang terjadi pada pelajar Madrasah Aliyah yang dipandang sebagai hal baru di luar kebiasaan berseragam di Madrasah tersebut. Menurutnya, perubahan gaya berjilbab tersebut dikhawatirkan dapat memicu respon negatif masyarakat yang sering mempersepsikan sebagai golongan Islam radikal yang membahayakan. Penelitian ini membahas proses perubahan memakai jilbab syar'i pada pelajar, motif yang melatarbelakanginya serta atribut yang berubah setelah memakai jilbab syar'i. Metode yang digunakan dalam penelitian ini adalah metode kualitatif dengan pendekatan fenomenologi. Pengumpulan data dilakukan melalui teknik wawancara dan observasi. Hasil penelitian menunjukkan bahwa proses perubahan menuju jilbab syar'i dilakukan secara lambat dengan memperlajari sumber buku dan internet tanpa berguru kepada ulama' yang memahami masalah syara' tentang jilbab. Terdapat dua motif yang melatarbelakangi pelajar memutuskan untuk beralih ke jilbab syar'i, yaitu motif untuk (motif because) berupa: motif agama, motif psikologis dan motif pertahanan. Kedua, motif tujuan (in-order-to motive) adalah: motif diterimanya amal dan motif mempebaiki amal ibadah. Adapun aspek yang berubah setelah pelajar mengenakan jilbab syar'i, yakni perubahan pada atribut fisik, perubahan pada 
aspek psikologi, dan perubahan pada idealisme dalam beribadah.

Pembeda penelitian penulis dengan penelitian Choliq juga berbeda bukan hanya pada siapa siapa yang diteliti, tetapi juga pada apa yang diteliti. Bila Choliq meneliti penggunaan jilbab pada pada Pelajar MA Al Irsyad Gajah, sementara penulis meneliti penggunaan jilbabpada mahasiswi komunikasi.Riset Choliq memokuskan kajian pada proses perubahan dan motif berjilbab, sementara penelitian penulis lebih terfokus pada makna dan motif di dalam menggunakan jilbab itu sendiri. Namun baik penelitian Choliq maupun penelitian, sama-sama menggunakan pendekatan fenomenologi.

Keempat, penelitian bertajuk Jilbab dalam Perspektif Sosiologis (Studi Pemaknaan di Fakultas Hukum Universitas Muhammadiyah Jakarta). Penelitian yang dilakukan Budiastuti ini menggali alasan, motif, atau hal-hal yang melatarbekangi seseorang berjilbab. Hasil penelitian menunjukkan bahwa makna jilbab di lingkungan Fakultas Hukum UMJ sebagai cara berpakaian yang bernuansa agama, yang direalisasikan dalam beragam bentuk dan model. Jilbab dipandang sebagai penutup dan pelindung tubuh, sekaligus memiliki fungsi mempercantik diri dan simbol identitas muslim. Dihadapkan pada kenyataan ini, maka jilbab di fakultas hukum UMJ, meski pada refleksi bertemunya beragam nilai, yaitu antara nilai kebaikan (moralitas dan identitas), kebenaran (norma dan praktek agama)m dan kebagusan (estetika dan mode), namun nilai kebagusanlah yang kebih menonjol di antara nilai-nilai lainnya.

Pembeda penelitian penulis dengan penelitian Budiastuti juga berbeda bukan hanya pada siapa yang diteliti, tetapi juga pada apa yang diteliti. Budiastuti memokuskan kajiannya pada pemakai jilbab di lingkungan Fakultas Hukum UMJ, sementara penulis memokuskan penelitian pada pengguna jilbab di kalangan mahasiswikomunikasi Universitas Tadulako Palu. Riset Budiastutimemokuskan kajian untuk menggali alasan, motif, atau hal-hal yang melatarbekangi seseorang berjilbab, sementara penelitian penulis lebih terfokus pada kajian motif dan makna pengguna jilbab itu sendiri. Pembeda lainnya, dalam pendekatan yang digunakan. Penelitian Budiastuti menggunakan pendekatan sosiologis, penelitian penulis menggunakan pendekatan fenomenologi.

Secara universal, jilbab sebagai identitas perempuan muslim juga sebagai identitas diri bagi pemakainya. Jilbab juga dipandang sebagai salah salah bentuk penampilan yang memiliki fungsi komunikatif bagi pemakai jilbab tersebut. Giddens (1991) dalam Barnard (2011:219) menyampaikan, identitas diri tercipta dari kemampuan untuk mempertahankan narasi perihal diri, dan dengannya membangun perasaan yang konsisten mengenai kesinambungan biografis.

Menurutnya, cerita identitas (identity story) adalah usaha menjawab pertanyaan penting: "Apa yang akan dilakukan? Bagaimana bertindak? Akan 
menjadi siapakah aku?" Individu berusaha membangun narasi identitas dengan "menyusun lintasan perkembangan diri dari masa lalu ke masa depan yang telah diantisipasi". Oleh karena itu, identitas diri bukan semata suatu ciri, atau sekumpulan ciri khas yang dimiliki individu, tetapi juga merupakan 'diri sebagaimana dipahami orang tersebut secara spontan terkait dengan biografinya'.

Identitas diri yang berkaitan penampilan memang sudah banyak digunakan oleh masyarakat di manapun mereka berada, termasuk penggunaan jilbab oleh para perempuan muslimah. Davis dalam Barnard (2011: 103) menyatakan, sudah menjadi klise bahwa pakaian yang kita kenakan mengungkapkan peryataan. Kebanyakan orang merasa, pakaian yang mereka pakai, memiliki atau dapat memberi makna tertentu.

Setiap individu dalam berintekasi memiliki pemaknaan tersendiri terhadap jilbab yang dikenakannya, sehingga setiap individu berlomba-lomba untuk menampilkan identitasnya melalui penampilan, agar orang lain dapat segera mengetahui identitas seperti apa yang sengaja ditunjukkannya, dan salah satunya adalah termasuk menggunakan jilbab.

Berpijak pada fenomena itu, maka penulis tertarik untuk mengkaji lebih dalam terkait pemaknaan perempuan muslimah di dalam menggunakan jilbab. Penelitian difokuskan pada mahasiswi berjilbab di Prodi Ilmu Komunikasi FISIP Universitas Tadulako. Penelitian bertujuan untuk mengetahui motif dan pemaknaan diri mahasiswi Ilmu Komunikasi FISIP Universitas Tadulako Palu di dalam memakai jilbab.

Secara etimologis, kata jilbab berasal dari bahasa Arab, dan bentuk jamaknya adalah jalabi. Jilbab adalah pakaian yang berfungsi untuk menutup aurat wanita ketika keluar rumah. Istilah jilbab di Indonesia pada awalnya dikenal sebagai kerudung untuk menutupi kepala (rambut) wanita hingga dada (Fitri; 2013:9). Al-Biqa'i (dalam Thohari, 2011) menyebutkan beberapa arti dari kata jilbab yaitu baju yang longgar atau kerudung penutup kepala wanita, atau pakaian yang menutupi baju dan kerudung yang dipakainya, atau semua pakaian yang menutupi badan wanita.

Dalam Tafsir Ayat Jilbab Kajian Terhadap QS al-Ahzab (33):59, Imam (2013) menegaskan bahwa jalabib adalah bentuk jamak kata jilbab, bentuk mashdar dari kata jalbaba, yang berasal dari satu rumpun kata jalaba, yang berarti menghimpun dan membawa. Ia juga berarti menutupkan sesuatu di atas sesuatu yang lain, sehingga tidak dapat dilihat. Jalabib sendiri dapat menutupi seluruh anggota badan. Di dunia Arab lebih dikenal dengan jalabiyyah, selain itu juga tajalbaba yang berarti "membajui."

Dalam kosakata bahasa Indonesia, menurut KBBI, jilbab adalah kerudung lebar yang dipakai perempuan muslim untuk menutupi kepala dan leher sampai ke dada. Secara umum, mereka yang menutupi bagian itu disebut orang yang berjilbab (2014:584). Untuk kepentingan penelitian ini, maka digunakan definisi 
jilbab adalah bagian pakaian atau busana kerudung yang wajib digunakan untuk menutupi kepala perempuan dalam hal ini rambut dan leher hingga ke dadanya. Berdasarkan penelitian yang telah dilakukan sebelumnya, keterbaruan dalam penelitian ini terletak pada penggalian motif, dan makna pada mahasiswi Ilmu Komunikasi FISIP Universitas Tadulako Palu yang memakai jilbab. Penelitian ini menggunakan pendekatan fenomenologi.

Ada dua teori yang peneliti pakai sebagai "pisau analisis" yakni teori fenomenologi dan inteaksi simbolik. Pertama, teori fenomenologi tidak bisa lepas dari Alfred Schutz, salah satu tokoh fenomenologi, dan juga setuju dengan Weber tentang pengalaman dan perilaku manusia dalam dunia sosial keseharian sebagai realitas yang bermakna secara sosial. Alase (2017) menyebutkan fenomenologi sebagai metodologi kualitatif yang mengizinkan peneliti menerapkan dan mengaplikasikan kemampuan subjektivitas dan interpersonalnya dalam proses penelitian eksploratori. Creswell (Eddles-Hirsch, 2015) menyatakan bahwa penelitian kualitatif adalah sebuah penelitian yang tertarik untuk menganalisis dan mendeskripsikan pengalaman sebuah fenomena individu dalam dunia sehari-hari.

Terkait dengan konsep tindakan sosial, Schutz sependapat dengan Weber. Konsep "sosial" dimaknai sebagai hubungan antara dua atau lebih orang. Adapun konsep "tindakan" dimaknai sebagai perilaku yang membentuk makna subjektif (subjective meaning). Dalam pandangan Schutz, makna subjektif bukan ada pada dunia privat, personal atau individual, namun terbentuk dalam dunia sosial oleh aktor berupa sebuah "kesamaan" dan "kebersamaan" diantara para aktor. Oleh karenanya sebuah makna subjektif disebut sebagai "intersubjektif". Selain makna "intersubjektif", dunia sosial, harus dilihat secara historis. Karenanya, Schutz menyimpulkan bahwa tindakan sosial adalah tindakan yang berorientasi pada perilaku orang atau orang lain pada masa lalu, sekarang, dan akan datang.

Teori kedua yakni interaksi simbolik yang dipopulerkan oleh George Herbert Mead. Teori ini memokuskan analisisnya pada sifat dan hakikat interaksi, ketika individu menginterpretasikan dan memberikan makna terhadap objek, peristiwa, dan situasi yang memungkinkan individu berpikir positif tentang orang lain. Sebagaimana dikemukakan Mead, teori interaksi simbolik dapat dirangkum dalam tiga konsep dasar yakni masyarakat (society), pikiran (mind), dan diri (self) (Little John, 2014:232). Interaksionisme simbolik mempelajari sifat interaksi yang merupakan kegiatan dinamis manusia. Hal ini berbeda dengan pendekatan struktural yang memokuskan pada individu dan ciriciri kepribadiannya atau bagaimana struktur sosial membentuk perilaku tertentu individu (Fakhruroji \& Muhaemin, 2017).

Dalam pandangan Mulyana, perspektif interaksi simbolik berusaha 
memahami perilaku manusia dari sudut pandang subjek. Dengan kata lain, manusia harus dilihat sebagai proses yang memungkinkan manusia membentuk dan mengatur perilaku mereka dengan mempertimbangkan ekspektasi (harapan) orang lain yang menjadi mitra interaksi mereka. Definisi yang mereka berikan kepada orang lain, situasi, objek, dan bahkan diri mereka sendirilah yang menentukan perilaku mereka. Intinya, manusia dikatakan bertindak hanya berdasarkan definisi atau penafsiran mereka atas objek-objek yang ada di sekitar mereka (2013:70).

Dalam kacamata interaksi simbolik, sebagaimana dikatakan Blumer (Mulyana, 2013:70), proses sosial dalam kehidupan kelompoklah yang menciptakan dan menegakkan aturan-aturan, bukan aturan-aturan yang menciptakan dan menegakkan kehidupan kelompok. Dalam konteks ini, makna dikonstruksikan dalam proses interaksi, dan proses tersebut bukanlah suatu medium netral yang memungkinkan kekuatan-kekuatan sosial memainkan perannya, melainkan justru merupakan substansi sebenarnya dari organisasi sosial dan kekuatan sosial.

Pendekatan fenomenologi didasarkan pada paradigma pengetahuan pribadi dan subjektivitas, serta menekankan pentingnya perspektif pribadi dan interpretasi. Berbagai data yang diperoleh baik dari wawancara, observasi maupun dokumentasi yang tertulis terkait penelitian berupaya untuk diolah, sehingga diperoleh gambaran yang jelas mengenai motif, dan makna mahasiswi yang memakai jilbab dengan menggunakan pendekatan fenomenologis.

Penelitian dilaksanakan di Prodi Ilmu Komunikasi FISIP Univesitas Tadulako Kota Palu Sulawesi Tengah. Penelitian ini dilaksanakan pada bulan Agustus sampai September tahun 2019. Dalam penelitian ini yang menjadi subjek adalah mahasiswi Ilmu Komunikasi yang masih aktif kuliah dengan tujuan untuk mendapatkan informasi dalam kaitannya dengan motif, dan makna mahasiswi yang memakai jilbab.

Dengan menggunakan purposive sampling, terpilih 5 informan. Kriteria utama dalam penentuan informan adalah bahwa partisipan dalam hal ini mahasiswi yang memiliki ketertarikan, memahami dan mengetahui makna menggunakan jilbab serta mau berpartisipasi dalam wawancara mendalam. Jumlah informan sebagaimana direkomendasikan John W. Creswell (2014: 108), eksplorasi pada kelompok individu yang telah mengalami fenomena tersebut. Individu diindentifikasi yang mungkin beragam dalam ukurannya dari 3 hingga 4 hingga 10 hingga 15 individu. Kemudian yang dijadikan objek dalam penelitian ini adalah pemaknaan, motif dan pengalaman interaksi.

Teknik pengumpulan data dilakukan dengan cara observasi, wawancara mendalam, dokumentasi, dan studi pustaka. Hasil penelitian tentang motif dan pemaknaan selanjutnya diolah dan dikategorikan sesuai tema. Data yang telah diperoleh atau dikumpulkan, diusahakan dicari makna yang terdapat dalam data 
tersebut kemudian dicoba untuk diambil kesimpulan yang ada, dan diverifikasi terus-menerus selama penelitian berlangsung.

\section{HASIL DAN PEMBAHASAN}

Sejumlah pakar mengatakan bahwa sebuah perilaku dan tindakan manusia yang sadar selalu didasari oleh motif. Motif merupakan suatu kekuatan atau dorongan yang datang dari dalam diri untuk bertindak atau berbuat sesuatu.

Berpijak pada hasil penelitian, informan pada penelitian ini, yaitu mahasiwa Ilmu Komunikasi FISIP Univesitas Tadulako Kota Palu juga memiliki motif di dalam menggunakan jilbab. Ada sejumlah motif yang melandasi mahasiswa di dalam menggunakan jilbab. Schutz menyebutnya dengan konsep motif, yang dibedakan menjadi dua pemaknaan dalam konsep motif, yaitu because motive dan in order motive, atau motif masa lalu dan motif masa depan. In order motive ini motif yang dijadikan pijakan oleh sesorang untuk melakukan sesuatu yang bertujuan mencapai hasil (Kaddi, 2018: 281).

\section{Motif Masa Lalu Menggunakan Jilbab}

Hasil penelitian yang berkaitan dengan motif dan pemaknaan diri menggunakan jilbab pada mahasiswa Ilmu Komunikasi FISIP Univesitas Tadulako menunjukkan bahwa pada setiap informan, selain ada persamaannya, tetapi juga memiliki perberbedaan satu sama lain. Berdasarkan hasil temuan di lapangan, peneliti menemukan dua motif mahasiswi di dalam menggunakan jilbab, yaitu motif masa lalu dan motif masa depan.

Terdapat 2 motif masa lalu yang mendasari mahasiswi menggunakan jilbab. Motif pertama, nasehat dari orang tua, keluarga, dan kerabat. Motif kedua, kewajiban yang sudah diatur dalam Islam. Dua orang informan mengatakan bahwa memakai jilbab, karena nasehat dari orang tua, keluarga, dan kerabat. Hal inilah yang memberikan motivasi dan pengetahuan agama para informan, sehingga memantapkan hati untuk kemudian memakai jilbab. Tiga informan lainnya mengaku memakai jilbab karena nasehat guru ngaji. Namun begitu, semua informan sepakat bahwa memakai jilbab merupakan kewajiban perempuan muslim dan ketentuan ini telah diatur dalam agama Islam sebagai agama yang mereka yakini.

Motif masa lalu pertama yang mendasari informan berjilbab, muncul karena dorongan orang tua, keluarga, kerabat, dan guru ngaji. Pengakuan ini diungkapkan para informan ini menunjukkan dengan jelas bahwa dorongan merekalah yang membuat para informan menggunakan jilbab. Ina mengakui bahwa motif masa lalu yang mendorongnya menggunakan jilbab adalah kedua orang tuanya. Berikut kutipan wawancara dengannya: 
"Terus terang, saya menggunakan jilbab karena dorongan dari kedua orang tua saya, terutama nasehat dari ibu, dan ayah yang sekali-kali memberikan pencerahan agar saya segera menutup aurat. Terus terang, dalam keluarga, ibu saya, kakak saya, dan adik saya semuanya sudah menutup aurat, hanya saya saja yang belum menggunakannya. Akhirnya bismillah, saya mulai menggunakan identitas muslim ini sekitar tiga tahun yang lalu, kalau nggake salah ingat.” (Ina, 25 September 2019)

Bila motif masa lalu Ina didasari dorongan orang tua, maka motif masa lalu Mutia menggunakan jilbab lebih disebabkan karena dorongan sepupunya, yang tak henti-hentinya mengingatkan dirinya untuk berjilbab. Berikut petikan wawancara dengannya:

Sebetulnya saya menggunakan jilbab, karena dorongan dari sepupu saya yang waktu itu sekolah di pesantren. Dan seingat saya, setiap kami ketemu, sepupu saya itu selalu mengingatkan saya untuk segera menutup aurat. Akhirnya malu juga saya kan, dan alhamdullillah saya sudah menutup aurat sekarang, (Mutia, 29 Agustus 2019)

Berbeda dengan Ina dan Mutia, motif masa lalu Wardah untuk berjilbab didasari motivasi kuat dari adik ayahnya. Hal ini seperti diakui Wardah ketika wawancara dengan peneliti:

Terus terang saya menggunakan jilbab, karena om saya, adik dari papa saya yang kepala sekolah di madrasah. Setiap saya ketemu dengan om saya, selalu dinasehati untuk segera menggunakan jilbab. Akhirnya dari situ saya mulai sadar bahwa memang sudah saatnya menggunakan jilbab (Wardah,15 September 2019).

Motif masa lalu kedua para informan menggunakan jilbab adalah kesadaran diri para informan akan keharusan wanita muslim menutup aurat. Para informan mengetahui bahwa mengenakan jilbab adalah kewajiban seorang muslimah yang sudah diatur dalam Alqur'an. Informan juga mengetahui bahwa perempuan harus menutup aurat. Para informan sangat percaya dengan mengenakan jilbab sebagai identitas muslim dalam berinteraksi dan beraktivitas sehari-hari, baik berinteraksi di dalam dunia kampus maupun di luar kampus.

Kenapa sib kita tidak memakai jilbab, sedangkan kita ini wanita muslim, beragama Islam. Setahu saya jelas kok disampaikan dalam Alqur'an, kalau menggunakan jilbab bagi muslimah itu adalah kewajiban. Kita tahu sendiri makna wajib itu apa.Memakai jilbab itu wajib hukumnya, karena Islam mewajibkan perempuan yang sudah baligh untuk menutup auratnya dengan berjilbab (Rahma, 1 September 2019). 
Kesadaran para informan menjalankan ajaran agama yang dianutnya serta ingin memperoleh ridha Allah SWT ini membuktikan bahwa kesadaran mereka mengenakan jilbab sebagai kewajiban menutupi auratnya. Jilbab sebagai pakaian muslimah, dan berjilbab merupakan perintah dari Allah yang harus dilaksanakan, dan berdosa bila tidak dilaksanakan. Bagi informan, manifestasi keimanan adalah menjalankan perintah agama, dan menjauhi larangan agama semata-mata hanya karena Allah. Setiap tindakan dan ibadah selalu didasarkan untuk mencari ridho Allah. Mereka yakin berjilbab itu sebagai kewajiban bagi muslimah.

Dalam pandangan Shihab, yang menyatakan bahwa kewajiban menggunakan jilbab adalah masalah khilafiah, jelas tidak berdasar. Sebab, para ulama ahli tafsir sejak dahulu hingga sekarang telah bersepakat tentang kewajiban memakai jilbab bagi kaum muslimah. Perintah ini didasari atas dalil baik dari Alqur'an maupun hadits dan qarinah (petunjuk) yang sangat kuat (Ratna, 2017).

\section{Motif Masa Depan Menggunakan Jilbab}

Temuan di lapangan yang berkaitan dengan motif masa depan mahasiswi menggunakan jilbab dapat dibagi menjadi tiga motif, yakni motif ingin menghindari hal-hal buruk, motif ingin mengontrol tingkah laku, dan motif ingin dihargai. Motif masa depan yang pertama, yakni motif ingin menghindari hal-hal yang buruk ada hubungannya dengan realitas pergaulan di era sekarang yang terkadang membuat sebagian mahasiswiterpedaya pada hal-hal yang tidak baik.Termasuk pada pergaulan dengan lawan jenis. Hal inilah yang kemudian mendorongmereka menggunakan jilbab sebagai motif menghindari diri dari halhal yang buruk, yang menjadi motif masa depan para informan berjilbab. Motif tersebut sebagaimana diakui informan:

Kalau menurut saya, perempuan dengan menggunakan pakaian tertutup, dan yang menutupi seluruh tubuhnya akan melindungi dirinya dari pergaulan dan godaan lawan jenis. Hal ini tentu berbeda dengan perempuan yang memakai pakaian terbuka yang akan membukapeluang laki-laki untuk menggodanya. Menurut saya, ini adalah tragedi keimanan, dan bisa menjadi penyebab tergodanya kaum perempuan oleh lawan jenis (Suci, 29 Agustus 2019).

Motif masa depan yang kedua, yakni motif ingin mengontrol tingkah laku dari perilaku yang tak semestinya dilakukan perempuan muslim. Dengan berjilbab, diakui informan, akan membuat dirinya untuk selalu menjaga dan mengontrol dirinya dari ucap, sikap, dan perilaku yang tak selayaknya dilakukan seorang perempuan muslim. Diakui pula, bahwa dengan menggunakan jilbab, dirinya menjadi sangat hati-hati dalam melakukan tindakan apapun. Penggunaan jilbab menjadi pengontrol ucap, sikap, dan perilakunya dalam pergaulan 
keseharian. Motif masa depan yang kedua ini seperti dituturkan informan berikut:

Menurut saya sih, akan ada perbedaan ketika kita menggunakan jilbab dengan tidak. Lebih kelihatan rapih, anggun, dan yang terpenting sib, ingin mengontrol perilaku saya. Karena jujur yah, percuma juga menutup aurat kalau kita sendiri tidak mampu mengontrol tingkah laku kita sehari-hari. Misalnya kalau berkomunikasi dengan seseorang yang bukan muhrim, kita ya harus jaga dirilah (Mutia, 23 September 2019).

Memakai jilbab diakui informan sangat berhubungan erat dengan tingkah laku pemakainya. Pasalnya, salah satu tujuan menggunakan jilbab, selain memenuhi perintah ajaran Islam, para pemakai jilbab juga paham bahwa Islam memandang perempuan sebagai suatu kehormatan yang wajib dijaga dan dipelihara. Menurut informan, Islam mensyariatkan penggunaan jilbab untuk menjaga dan memelihara kehormatana perempuan itu sendiri. Nabi SAW bersabda: "Perempuan adalab aurat". Dalam pandangan informan, ini mengandung makna bahwa tubuh perempuan itu harus ditutupi sebagai aurat yang merupakan kehormatan baginya. Jika aurat diperlihatkan pada orang yang tidak berhak, sejatinya perempuan itu sedang melecehkan kehormatan dirinya.

Motif masa depan yang ketiga, yakni motif ingin dihargai. Dengan berjilbab, para informan yakin dirinya akan dihargai, dan dihormati sebagai perempuan muslim yang baik. Jilbab juga dinilai sebagai identitas kemuslimahan dirinya yang akan mendorong siapapun untuk menghargai dan menghormatinya sesuai status dirinya sebagai perempuan muslim. Berkaitan dengan keinginan mereka untuk dihargai ini, dua di antaranya sebagaimana diungkapkaninforman di bawah ini:

Jilbab itu identitas keagamaan. Jilbab merupakan pakaian penutup aurat bagi kaum hawa yang beragama Islam, dan ini menjadi cerminan diri dari pemakainya. Jilbab juga dapat mencerminkan status sosial dan karakter seseorang. Dari jilbab yang dikenakan, kita dapat melihat seseorang tersebut menganut agama apa, dan karakter seseorang tersebut seperti apa (Ina, 27 September 2019)

Jilbab sebagai simbol identitas diri seorang muslimah, karena dengan identitas ini kita bisa menjaga kehormatan diri kita dari pandangan kaum laki-laki, atau meminimalisir godaan atau kejahatan dari laki-laki. (Rahma, 1 September 2019)

Mengenakan jilbab bagi seorang muslimah adalah kewajiban sesuai dengan ajaran agama Islam dalam mejalankan perintah agama. Hal ini pun telah diatur di dalam Al-Quran. Lebih tepatnya berada dalam surat Al-Ahzab ayat 59 dan surat An-Nur ayat 31. Seorang muslimah siap atau tidak siap harus memakai 
jilbab, bagaimana pun perilaku dan kondisinya, perintah jilbab ini di analogikan seperti perintah shalat di mana setiap orang telah baligh diwajibkan melaksanakan perintah tersebut.

Begitu pun dengan penggunaan jilbab tidak bisa dilepaskan dari persoalan aurat. Membahas mengenai aurat dalam konteks agama Islam adalah tentang bagian-bagian tubuh atau sikap dan kelakuan yang rawan, dan dapat mengundang bahaya. Aurat dipahami sebagai sesuatu yang hendaknya diawasi karena aurat itu rawan dan dapat menimbulkan bahaya serta rasa malu. Hal ini dilakukan demi keamanan perempuan tersebut dari bahaya-bahaya yang dapat mengintai karena cara berpakaian mereka kurang rapi dan belum menutup aurat. Oleh sebab itu, berjilbab merupakan salah satu dari banyak hal yang wajib dilakukan dalam tata cara berpakaian, khususnya untuk menutup aurat.

Miranda (2014:6) berpendapat, bahwa cara berpenampilan mampu menunjukkan tentang bagaimana kita ingin diperlakukan oleh orang lain, karena penampilan memiliki pengaruh yang besar dalam membentuk citra diri atau kesan terhadap pemakainya. Sebagai sistem simbol yang memiliki makna, jilbab menjadi ciri yang dapat menjelaskan "siapa"seseorang di dalam masyarakat serta membedakan dengan individu lain, sehingga jilbab menjadi identitas yang melekat pada diri seseorang.

Dalam teori fenomenologi, Schutz memperkenalkan dua istilah motif. Motif pertama, motif "sebab" (because of motive), yang dalam penelitian ini penulis sebut sebagai motif masa lalu. Motif ini berkaitan dengan alasan seseorang melakukan sesuatu tindakan sebagai usahanya menciptakan situasi dan kondisi yang diharapkan di masa datang. Dalam kata lain because of motive ini adalah motif yang melatarbelakangi seseorang melakukan tindakan tertentu.

Motif kedua, motif "tujuan" (in order to motive), yang dalam penelitian ini disebut motif masa depan. Motif ini berkaitan dengan motif yang ingin dicapai oleh seseorang yang melakukan suatu tindakan tertentu. In order to motive merupakan pandangan retrospektif terhadap faktor-faktor yang menyebabkan seseorang melakukan tindakan tertentu. Dengan kata lain in order to motive adalah tujuan yang ingin dicapai oleh seseorang yang melakukan suatu tindakan tertentu.

\section{Makna Berjilbab}

Temuan penelitian yang berkaitan dengan makna penggunaan jilbab bagi mahasiswi Ilmu Komunikasi FISIP Univesitas Tadulako Palu adalah sebagai bukti sayang kepada Allah, dan sebagai tanda bakti kepada kedua orang tua. Dua informan penelitian mengatakan bahwa mereka menggunakan jilbab sebagai bukti sayang dan cinta kepada Allah SWT, dan semua informan sebanyak lima 
orang mengatakan bahwa mereka menggunakan jilbab sebagai salah satu bukti untuk berbakti kepada kedua orang tua.

Makna pertama menggunakan jilbab sebagai bukti sayang kepada Allah SWT. dikemukakan dua orang informan. Keduanya memiliki pendapat senada bahwa menggunakan jilbab dimaknainya sebagai bukti dan cintanya kepada Allah SW'T.

Saya ini takut dosa.Ada tekanan dosa kepada Allah, di sisi lainnya saya juga sayang kepada Allah. Karena seluruh tubuh wanita itu adalah amanah yang diberikan Allah SWT., maka sudah selayaknya saya menyanyangi Allah dengan cara apa? Saya menjaga amanah tersebut, dengan cara menutup aurat (Wardah, 15 September 2019).

Makna kedua menggunakan jilbab sebagai bakti kepada Allah SWT. dikemukakan semua informan. Kelima informan memiliki pandangan senada bahwa menggunakan jilbab dimaknainya sebagai bakti kepada orang tua. Informan menegaskan bahwa kedua orang tuanya adalah sosok manusia yang harus dimuliakan. Memuliakan keduanya dapat dilakukan dengan memosisikan orang tua dengan penuh cinta dan memperlakukannya dengan baik, karena orang tua berhak dan mempunyai hak menerima perlakuan anaknya. Bukti utama bahwa berbakti kepada kedua orang tua merupakan salah satu ajaran Islam yang paling tinggi setelah iman kepada Allah SWT.

Semua informan yang memaknai penggunaan berjilbab sebagai bakti terhadap kedua orang tua, dapat dilihat dari penegasan informan berikut:

Saya ingin menghadiahi orang tua saya kelak di surga mahkota di kepala mereka berdua sebagai bakti saya terhadap keduanya. Saya yakin ini, karena ini janji Allah. Sebagai seorang anak tentu saya tidak akan menyianyiakan kesempatan ini. Karena itu, bagi saya, memakai jilbab menjadi penting, sebagai bakti anak kepada kedua tua (Ina, 25 September 2019).

Dalam teori interaksi simbolik, makna tidak bisa dilepaskan dari proses komunikasi. Ini dapat dimengerti, karena awalnya makna itu tidak ada artinya, sampai pada akhirnya dikonstruksi secara interpretatif oleh individu melalui proses interaksi. Hal ini, menurut Siregar (2011), sejalan dengan tiga dari tujuh asumsi Blumer, yakni: (1). Manusia bertindak terhadap manusia lainnya berdasarkan makna yang diberikan orang lain kepada mereka; (2). Makna diciptakan dalam interaksi antar manusia; dan (3) Makna dimodifikasi melalui proses interpretif.

Herbert Mead menegaskan bahwa di dalam teori interaksi simbolik, terkandung tiga konsep utama yaitu mind, self dan society. Mead mendefinisikan pikiran (mind) sebagai kemampuan untuk menggunakan simbol yang mempunyai makna sosial yang sama, dan Mead percaya bahwa manusia harus 
mengembangkan pikiran melalui interaksi dengan orang lain, dengan menggunakan bahasa. Diri (self) didefinisikan sebagai kemampuan untuk merefleksikan diri kita sendiri dan perspektif orang lain. Mead tidak percaya bahwa diri berasal dari instropeksi diri atau pemikiran sendiri yang sederhana. Menurut Mead diri berkembang dari sebuah jenis pengambilan peran yang khusus. Mead menyebut sebagai subjek atau diri yang bertindak sebagai $I$ dan objek atau diri yang mengamati adalah $M e$. Diri adalah sebuah proses yang mengintegrasikan antara $I$ dan $M e$ (West \& Turner, 2012: 106).

Penganut interaksi simbolik berpandangan, perilaku manusia pada dasarnya adalah produk dari interpretasi mereka atas dunia di sekeliling mereka. Perilaku dipilih berdasarkan bagaimana individu menafsirkan situasinya. Teori interaksi simbolik dalam penelitian ini berkontribusi sebagai dasar pemikiran bahwa dalam pemaknaan diri memakai jilbab bagi mahasiswa ilmu komunikasi FISIP Universitas Tadulako, menciptakan dan memberikan makna mengenai penggunaan jilbab dan sebagai bagian dari kegiatan pemberian informasi kepada publik ketika para informan melakukan komunikasi dan berinteraksi dalam lingkungan kampus.

Dengan berpijak pada teori interaksi simbolik, penulis menemukan bahwa tindakan yang dilakukan para mahasiswa komunikasi FISIP Universitas Tadulako dalam membentuk dan memberikan makna di dalam interaksi, juga dilakukan melalui jilbab sebagai simbol dalam berkomunikasi. Intinya, ada makna yang dipertukarkan dalam proses interaksi yang mereka lakukan seharihari. Jilbab menjadi simbol yang dimaknai bukan hanya seabagai ketaatan kepada Allah SWT., tapi juga dimaknai sebagai bukti bakti kepada kedua orang tua.

Menurut perspektif fenomenologi Alfred Schutz (dalam Sobur, 2013: 65), dunia sosial tidak berasal dari penemuan manusia itu sendiri tetapi diturunkan secara sosial dari orang-orang sebelumnya. Bisa dikatakan bahwa tindakan manusia merupakan hal yang dilihat dan ditiru dari lingkungan sosial mereka. Hal ini pula yang menjadikan bahwa menggunakan jilbab karena hasil interaksi yang terjadi secara terus-menerus dan berkesinambungan dengan harapan penggunaan jilbab bisa memberikan ruang bagi informan untuk dihargai ketika para informan berinteraksi dan berkomunikasi dengan yang bukan muhrimnya.

Demi rasa keamanan dan menjaga diri, tidak dapat dipungkiri bahwa akhir-akhir ini semakin banyak dan kian menyeruak tindak kejahatan seksual seperti pemerkosaan, dan pelecehan seksual yang menimpa kaum wanita. Tidak mengherankan bila kemudian menutup aurat atau menggunakan jilbab menjadi pilihan, bukan sekadar untuk menghindari hari hal-hal buruk, dan keinginan untuk dihargai, tetapi juga untuk melakukan kontrol atas perilaku diri pemakaiannya. Dengan berjilbab, informan merasa mempunyai tanggung-jawab moral untuk tidak rnelakukan hal-hal yang tercela yang kadang-kadang sulit 
dihindari. Lebih jauhnya, jilbab menyebabkan terjadinya perubahan tingkah laku sesuai yang diharapkan dan lebih menonjolkan perilaku islami ketika para informan berinteraksi dengan teman-teman pria.

Sebagai simbol yang memiliki makna, jilbab menjadi ciri yang dapat menjelaskan 'siapa' seseorang dalam masyarakat serta membedakannya dengan individu lainnya, sehingga akhirnya jilbab menjadi identitas yang melekat pada diri seseorang. Islam datang dengan keadilan dan persamaan antara laki-laki dan perempuan serta menghormati harkat dan martabat secara sama. Dengan cara ini, Islam memperluas ruang peran dan memenuhi hak-hak perempuan secara sempurna, sekaligus menghargai sisi kemanusiaan, kemuliaan, dan derajat kaum perempuan. Tentunya juga dalam keterkaitannya dengandunia kerja dalam mengemban tugas yang menjadi tanggung-jawabnya. Jilbab dipandang informansebagai perintah yang sangat jelas dari Allah SWT dan Rasul-Nya, sehingga mengenakan jilbab merupakan bentuk ketaatan dan keimanan wanita kepada Allah SWT dan ketaatan kepada Rasul-Nya. Lebih dari itu, berjilbab merupakan kewajiban atas setiap muslimah yang sudah baligh.

Sebagai identitas seorang muslimah, jilbab adalah benteng bagi wanita muslim dan berhubungan dengan posisi wanita dalam sistem Islam yang disyariatkan Allah SWT. Tujuannya agar menjadi benteng kokoh yang mampu melindungi kaum wanita, menjadi pagar pelindung yang mampu melindungi ketika melakukan interaksi dan komunikasi dengan masyarakat khususnya kelompok masyarakat yang berlawanan jenis

\section{PENUTUP}

Berpijak pada hasil penelitian, maka ada dua simpulan penting yang dapat dikemukakan, baik terkait dengan motif maupun terkait dengan makna. Kedua simpulan itu sebagai berikut:

Pertama, motif mahasiswi memakai jilbab mahasiswa Ilmu Komunikasi FISIP Universitas Tadulako Palu terbagi menjadi dua, yaitu motif masa lalu dan motif masa depan. Motif masa lalu terbagi menjadi dua, yakni memakai jilbab karena nasehat dari orang tua dan keluarga, dan memakai jilbab karena kewajiban dan sudah diatur dalam agama Islam. Adapun motif masa depan mahasiswi menggunakan jilbab dibagi menjad dua (2) yakni ingin menghindari hal-hal buruk, ingin mengontrol tingkah laku, dan ingin dihargai.

Kedua, makna diri memakai jilbab di bagi menjadi 2 (dua), yakni bukti sayang kepada Allah, dan sebagai bakti kepada kedua orang tua. Bahwa informan yang memahami perintah untuk menggunakan jilbab sebagai sebuah kewajiban, memaknai penggunaan jilbab dan perintahnya sebagai sesuatu yang wajib karena sudah tercantum di dalam Alqur'an. Sedangkan informan yang memahaminya sebagai sesuatu yang dapat meminimalisir kejahatan. 


\section{DAFTAR PUSTAKA}

Alase, A. (2017). The Interpretative Phenomenological Analysis (IPA): A Guide to a Good Qualitative Reseach Approach. International Journal of Education and Literacy Studies, 5(2). DOI: 10.7575/aiac.ijels.v.5n.2p.9

Asis, P.H. (2017). Makna Berhijab Bagi Muslimah: Sebuah Persepsi Mahasiswa FISIP Universitas Muhammadiyah Kendari. Jurnal Dakwah Tabligh. 18(2) 2017.

Barnard, M. (2011). Fashion sebagai Komunikasi, Cara Mengomunikasikan Identitas Sosial, Seksual, Kelas, dan Gender. Yogyakarta: Jalasutra.

Budiastuti. (2012). Jilbab dalam Perspektif Sosiologis (Studi Pemaknaan di Fakultas Hukum Universitas Muhammadiyah Jakarta). Depok: Tesis. FISIP Program Pasca Sarjana UI.

Choliq, A. (2018). Proses dan Motif Berjilbab Standar ke Syar'i pada Pelajar MA Al Irsyad Gajah. Islamic Comunication Journal/Volume, 3(2)

Eddles-Hirsch, K., (2015). Phenomenology and Educational Research. International Journal of Advanced Research, 3(8).

Fitri, I., \& Nurul R.A.K. (2013). 110 Kekeliruan Dalam Beriilbab. Jakarta Timur: Al- Magfirah

Fakhruroji, M., \& Muhaemin. (2017). Akademisi Dakwah Terhadap Internet Sebagai Media Dakwah. Jurnal Sosioteknologi, 16 (1).

Hanifah, M. (2015). Pemaknaan Jilbab Kreatif bagi Perempuan Muslim sebagai Identitas Diri. Jurusan Ilmu Komunikasi Fakultas Ilmu Sosial dan Ilmu Politik Universitas Diponegoro

Imam, T. (2013). Tafsir ayat jilbab kajian terhadap QS al-Ahzab (33): 59. Jurnal AtTaqaddum, 5(2).

Kaddi, S. M. (2018). Dialektika Komunikasi Suami Istri Pada Perkawinan Beda Etnik. (Studi Kasus Pada Pasangan Etnike Bugis dan Kaili di Kota Palu Sulawesi Tengah). Disertasi. Univesitas Padjadjaran.

Kamus Besar Bahasa Indonesia Pusat Bahasa. (2014). Jakarta: Gramedia Pustaka.

Littlejohn, S. W. (2014). Theories of Human Communication (9 th ed), terjemahan, Jakarta, Salemba Humanika

Miranda, R., \& Jenahara. (2014). Fashion Friendship. Jakarta: QultumMedia.

Mulyana, D. (2013). Metodologi Penelitian Kualitatif: Paradigma Baru Ilmu Komunikasi dan Ilmu Sosial Lainnya. Bandung: Remaja Rosdakarya.

Muchtar, K., Koswara, I., \& Setiaman, A. (2016). Komunikasi Antar Budaya dalam Persefektif Antropologi. Jurnal Manajemen Komunikasi, 1(1), 113124.

Sada, H. J. (2015). Konsep Pembentukan Kepribadian Anak Dalam Perspektif AlQur'an (Surat Luqman Ayat 12-19). Al-Tadzkiyyah: Jurnal Pendidikan Islam, 6(2), 253-272. 
Sitti Murni Kaddi \& Enjang Muhaemin

Siregar, N. S. S. (2011). Kajian Tentang Interaksionisme Simbolik. Jurnal Ilmu Sosial Fakultas ISIPOL UMA: PERSPEKTIF, 4(2).

Sobur, A. (2013). Filsafat Komunikasi Tradisi dan Metode Fenomenologi. Bandung: Remaja Rosdakarya.

Sulthoni, A. N. (2010). Studi Interaksionisme Simbolik tentang Makna Sneaker dalam Komunitas Sneakerhead di Surabaya. Surabaya: Universitas Airlangga.

Thohari, C. (2011). Konstruksi Pemikiran Quraish Shihab tentang Hukum Jilbab: Kajian Hermeneutika Kritis. Malang: Jurnal, 14(1)

Utari, N. P., \& Siregar, N. S. (2015). Pemaknaan Penggunaan Jilbab Syar'i diKalangan Mahasiswa Psikologi (Studi pada Forum Mahasiswa Islam Psikologi ( FORMASI ) Ar-Ruuh Universitas Medan Area). Jurnal Simbolika, 1(1).

West, R. \& Turner, H. L. (2012). Pengantar Teori Komunikasi: Analisis dan Aplikasi. Jakarta: Salemba Humanika.

Wijayanti, R. (2017). Jilbab Sebagai Etika Busana Muslimah dalam Perspektif AlQur'an. Cakrawala: Jurnal Studi Islam, XII (2). 